\title{
Use of isoptin for counteracting the effect of methol on cardiac activity in experimental animals
}

\author{
J. Domahidii ${ }^{1,2}$, Katica Péter ${ }^{2}$, Judit Farkas ${ }^{3}$ \\ ${ }^{1}$ Medical and Pharmaceutical University Tg-Mureş, \\ ${ }^{2}$ Public Health Center Tg-Mureș, \\ ${ }^{3}$ II. Infectious Disease Clinic Tg-Mureș, Romania
}

Received: July 8, 1999

Accepted: November 9, 1999

The purpose of the present study is to use isoptin in order to lower intracellular $\mathrm{Ca}^{2+}$ concentration for counteracting the effect of methol on cardiac activity in acute intoxication of the experimental animals. Adult male Wistar rats were used -8 animals/lot anaesthesized with urethan. ECG activity was recorded every 15 minutes, for 360 minutes. Administration (oral) of methol in a dose of $310 \mathrm{mg} / \mathrm{kg} / \mathrm{bw}$. $\left(\mathrm{DL}_{100}\right)$ produced sinusal bradycardia, which became more marked later on. Isoptin administration in a dose of $5 \mathrm{mg} / \mathrm{kg} / \mathrm{bw}$. in rats with $310 \mathrm{mg} / \mathrm{kg} / \mathrm{bw}$. methol decreased the heart rate, the lowest value occurring 120 minutes after administration, followed by a slow increase until the end of the recording. When isoptin was given in a dose of $2.5 \mathrm{mg} / \mathrm{kg} / \mathrm{bw}$. to rats with $310 \mathrm{mg} / \mathrm{kg} / \mathrm{bw}$. methol, the decrease of the heart rate was much slower than before, for a period of 255 minutes, followed by a slight increase until the end of the recording. Isoptin counteracts the bradycardia - producing effect of methol in rats during the study time (6 hours), and the effect after this period of time requires further investigations.

Keywords: methol, isoptin, cardiac activity

One of the most important factors of regulating the muscular cell activity is the calcium amount and its distribution in the cell compartments [7]. The difference between intra- and extracellular $\mathrm{Ca}^{2+}$ concentrations is ensured by the $\mathrm{Ca}^{2+}$ pump mediated by ATP and Na-Ca exchange channels of the plasmic membrane [19].

Correspondence should be addressed to

Dr. János Domahidi

Public Health Center Tg-Mureș

4300 Tg-Mureș, Gh. Marinescu str. 40, Romania

Phone: 0040-065-215754

Fax: 0040-065-219320

E-mail: CMSSC@netsoft.ro 
At rest the concentration of cytoplasmic $\mathrm{Ca}^{2+}$ decreases from $10^{-7}$ to $10^{-8}$, and the $\mathrm{Ca}^{2+}$ concentration gradient between the two surfaces of the membrane of the sarcoplasmic reticulum (SR) is $10^{-3}$. This calcium gradient needs the presence and the activation of the $\mathrm{Ca}^{2+}$ pump on the surface of the cellular and intracellular membranes [8].

The skeletal muscles with intense activity require the rapid movement of a big amount of $\mathrm{Ca}^{2+}$, which cannot be made by sarcoplasmic transports. The presence of greatly extended SR made is possible to meet this requirement $[9,15]$. There is a close connection between the tanks of the longitudinal sarcoplasmic tubes and T tubes; at this level there are Ryanodin receptors for the $\mathrm{Ca}^{2+}$-releasing channels [16]. Some recent observations have confirmed the idea of double regulation of voltage and $\mathrm{Ca}^{2+}$ dependent of the $\mathrm{Ca}^{2+}$-releasing channels in SR $[12,18]$.

After the phase of muscular cell activation, the decrease of cytoplasmic $\mathrm{Ca}^{2+}$ is due to the activation of SR $\mathrm{Ca}^{2+} \mathrm{ATP}$-ase [11]. In the cardiac muscles, where SR is less developed, the activation of $\mathrm{Ca}^{2+} \mathrm{ATP}$-ase in the cell membrane and the $\mathrm{Ca}^{2+}$ reception by the mitochondria have an important role in $\mathrm{Ca}^{2+}$ transport [10]. Methol reduces $\mathrm{Ca}^{2+}$ ATP-ase activity; like hydroquinone it is a reducer in the form of crystals of various sizes, and it is found in the composition of the solutions processing photosensitive materials. If the rules of hygiene are not observed when handled, they can penetrate into the body. The toxicity of hydroquinone on the human body, as well as on the cardiovascular system is described in many papers of special literature, the highest concentration accepted at work-place being precribed by the law. We have not found any data concerning the effect and action mechanism of methol. This fact has made us study the action of methol on the cardiac activity in experimental animals and the use of certain "antidotes" in order to counteract the effect of methol.

To purpose of thie study is to use isoptin as a calcium-channel blocker with a view to lower intracellular $\mathrm{Ca}^{2+}$ concentration for counteracting the effect of methol on the cardiac activity in acute intoxication of experimental animals.

\section{Materials and methods}

We used adult Wistar rats (180-200 g) grouped in 5 lots having 8 animals each: the first lot, the controls, were given $0.5 \mathrm{ml}$ distilled water orally, through a stomach tube; the second lot received $310 \mathrm{mg} / \mathrm{kg} / \mathrm{bw}$. methol; in the third lot $5 \mathrm{mg} / \mathrm{kg} / \mathrm{bw}$. isoptin was administered; the fourth lot received $310 \mathrm{mg} / \mathrm{kg} / \mathrm{bw}$. methol followed by $5 \mathrm{mg} / \mathrm{kg} / \mathrm{bw}$. isoptin; the fifth lot animals were given $310 \mathrm{mg} / \mathrm{kg} / \mathrm{bw}$. methol followed by $2.5 \mathrm{mg} / \mathrm{kg} / \mathrm{bw}$. isoptin. 
Process of determination: weighing the animals, anaesthetizing with doses of $1000 \mathrm{mg} / \mathrm{kg} / \mathrm{bw}$. urethan administered intraperitoneally. 30 minutes after urethan administration the first ECG curve was recorded (control, $\mathrm{t}=0$ ), followed by recordings every 15 minutes for 6 hours. Methol was administered 30 minutes after urethan administration (immediately after recording the first ECG curve), and isoptin 30 minutes after methol administration. The dissolution of urethan and methol was made with $0.5 \mathrm{ml}$ distilled water before administration. Urethan and isoptin were given intraperitoneally. Depending on the lots, methol was administered orally on an empty stomach, through stomach tube, in a dose of $310 \mathrm{mg} / \mathrm{kg} / \mathrm{bw}$. This dose represented $\mathrm{DL}_{100}$, which produced the death of all animals. Both methol and isoptin were administered in a single dose. Cardiac electric activity was recorded with a portable Toshiba apparatus at a speed of $50 \mathrm{~mm} / \mathrm{sec}$, in standard derivation III. After reading the $\mathrm{R}-\mathrm{R}$ interval in msec from the ECG curves, the data were processed by computer, the mean values and standard deviations of the heart rate were calculated, and in testing the significant differences we used Student's test, considering the significant differences when $\mathrm{p}<0.05$.

Methol: methyl-4-aminophenolsulphate $\left(\mathrm{HOC}_{6} \mathrm{H}_{4} \mathrm{NHCH}_{3}\right)_{2} \mathrm{H}_{2} \mathrm{SO}_{4}$ from the Factory of Photosensitive Materials at Tg.-Mureş, as white crystals, is a component of the solutions used in processing photosensitive materials, ensuring the reduction of silver ions to form visible images. It is an allergen with reduced potential of sensitivity [13]

Isoptin: vials of $2 \mathrm{ml} / 5 \mathrm{mg}$ verapamilhydrochlorid, calcium-channel blocker.

\section{Results}

The effect of isoptin on the heart rate: isoptin given intraperitoneally in a dose of $5 \mathrm{mg} / \mathrm{kg} / \mathrm{bw}$. gradually decreases the heart rate. The lowest value is obtained 90 minutes after administration, and then the heart rate is gradually restored. After 225 minutes it has almost the same value as the controls (Fig. 1). It does not bring about any significant modifications in the heart rate as compared with the control group (Table I).

The effect of isoptin in a dose of $5 \mathrm{mg} / \mathrm{kg} / \mathrm{bw}$. on the heart rate when $310 \mathrm{mg} / \mathrm{kg} / \mathrm{bw}$. methol is administered (Fig. 2): after administering $5 \mathrm{mg} / \mathrm{kg} / \mathrm{bw}$. isoptin the heart rate decreases suddenly, the lowest value being reached after 150 minutes, followed by a slow increase until the end of the recording when its mean value is 270.40 /minute. This decrease becomes significant after 60 minutes in comparison with the controls, and it remains significant up to the end of the recording. 
Table I

Data concerning the heart rate changes due to methol in the presence of isoptin in rats

\begin{tabular}{|c|c|c|c|c|c|c|c|c|c|}
\hline \multirow[t]{2}{*}{ Time } & $0^{\prime}$ & $15^{\prime}$ & $30^{\prime}$ & $60^{\prime}$ & $120^{\prime}$ & $180^{\prime}$ & $240^{\prime}$ & $300^{\prime}$ & $360^{\prime}$ \\
\hline & \multicolumn{9}{|c|}{ (minutes) } \\
\hline \multicolumn{10}{|l|}{ Control } \\
\hline heart rate & 430.1 & 393.7 & 392.7 & 403.7 & 385.3 & 400.4 & 399.1 & 383.3 & 411.2 \\
\hline stdev & 50.56 & 74.09 & 61.49 & 44.42 & 55.38 & 50.70 & 60.13 & 62.08 & 48.57 \\
\hline \multicolumn{10}{|c|}{ Isoptin $5 \mathrm{mg} / \mathrm{kg} / \mathrm{bw}$. ip. } \\
\hline heart rate & 450.8 & 419 & 395.3 & 379.3 & 375 & 372.8 & 385.8 & 388 & 396.5 \\
\hline stdev & 34.03 & 27.53 & 46.36 & 54.16 & 50.88 & 36.98 & 31.48 & 27.33 & 22.66 \\
\hline $\mathrm{p}$ & 0.442 & 0.440 & 0.940 & 0.475 & 0.764 & 0.328 & 0.640 & 0.866 & 0.464 \\
\hline \multicolumn{10}{|c|}{ Methol $310 \mathrm{mg} / \mathrm{kg} / \mathrm{bw}$. orally } \\
\hline heart rate & 404.4 & 370.2 & 363.8 & 360.4 & 355.6 & 321.4 & 323.8 & 297 & 285.2 \\
\hline stdev & 60.3 & 61.45 & 58.95 & 44.34 & 45.57 & 52.2 & 67.35 & 60.31 & 62.11 \\
\hline $\mathrm{p}$ & 0.459 & 0.562 & 0.431 & 0.131 & 0.334 & 0.029 & 0.08 & 0.039 & 0.006 \\
\hline \multicolumn{10}{|c|}{ Methol $310 \mathrm{mg} / \mathrm{kg} / \mathrm{bw} .+$ isoptin $2.5 \mathrm{mg} / \mathrm{kg} / \mathrm{bw}$. } \\
\hline heart rate & 433.6 & 426 & 398.2 & 394.2 & 368.2 & 343.6 & 324.8 & 325 & 328.2 \\
\hline stdev & 23.89 & 29.79 & 49.82 & 46.28 & 80.82 & 70.13 & 63.6 & 57.68 & 66.71 \\
\hline $\mathrm{p}$ & 0.878 & 0.326 & 0.868 & 0.729 & 0.695 & 0.166 & 0.073 & 0.128 & 0.046 \\
\hline \multicolumn{10}{|c|}{ Methol $310 \mathrm{mg} / \mathrm{kg} / \mathrm{bw} .+$ isoptin $5 \mathrm{mg} / \mathrm{kg} / \mathrm{bw}$. } \\
\hline heart rate & 384.8 & 361 & 353.8 & 283.6 & 263.6 & 263.2 & 266.2 & 271 & 270.4 \\
\hline stdev & 41.38 & 55.38 & 44.46 & 49.08 & 42.94 & 40.74 & 27.39 & 23.02 & 25.13 \\
\hline $\mathrm{p}$ & 0.12 & 0.402 & 0.232 & 0.002 & 0.001 & 0.000 & 0.000 & 0.002 & 0.000 \\
\hline
\end{tabular}

The effect of isoptin in a dose of $2.5 \mathrm{mg} / \mathrm{kg} / \mathrm{bm}$. on the heart rate when $310 \mathrm{mg} / \mathrm{kg} / \mathrm{bw}$. methol is administered (Fig. 3): after administering $2.5 \mathrm{mg} / \mathrm{kg} / \mathrm{bw}$. isoptin the heart rate falls for 240 minutes, followed by a slight rise till the end of the recording when the mean value of the heart rate is 328.20 /minute. This decrease is not significant as compared with the controls (Table I).

Figure 4 presents the heart rate curves of all the lots studied in comparison with one another. This reveals that the use of isoptin in a dose of $2.5 \mathrm{mg} / \mathrm{kg} / \mathrm{bw}$. in the lot with $310 \mathrm{mg} / \mathrm{kg} / \mathrm{bw}$. methol administration produces a slower decrease of the heart rate, and this decrease is not significant against the control group. The use of $5 \mathrm{mg} / \mathrm{kg} / \mathrm{bw}$. isoptin in the lot with $310 \mathrm{mg} / \mathrm{kg} / \mathrm{bw}$. methol causes a sudden fall of the heart rate, which is partly restored at the end of the recording. This decrease is significant after 60 minutes and it remains significant till the end of recording. The two rate curves of methol $+2.5 \mathrm{mg} / \mathrm{kg} / \mathrm{bw}$. isoptin and methol $+5 \mathrm{mg} / \mathrm{kg} / \mathrm{bw}$. isoptin are parallel after 255 minutes till the end of the recording. 


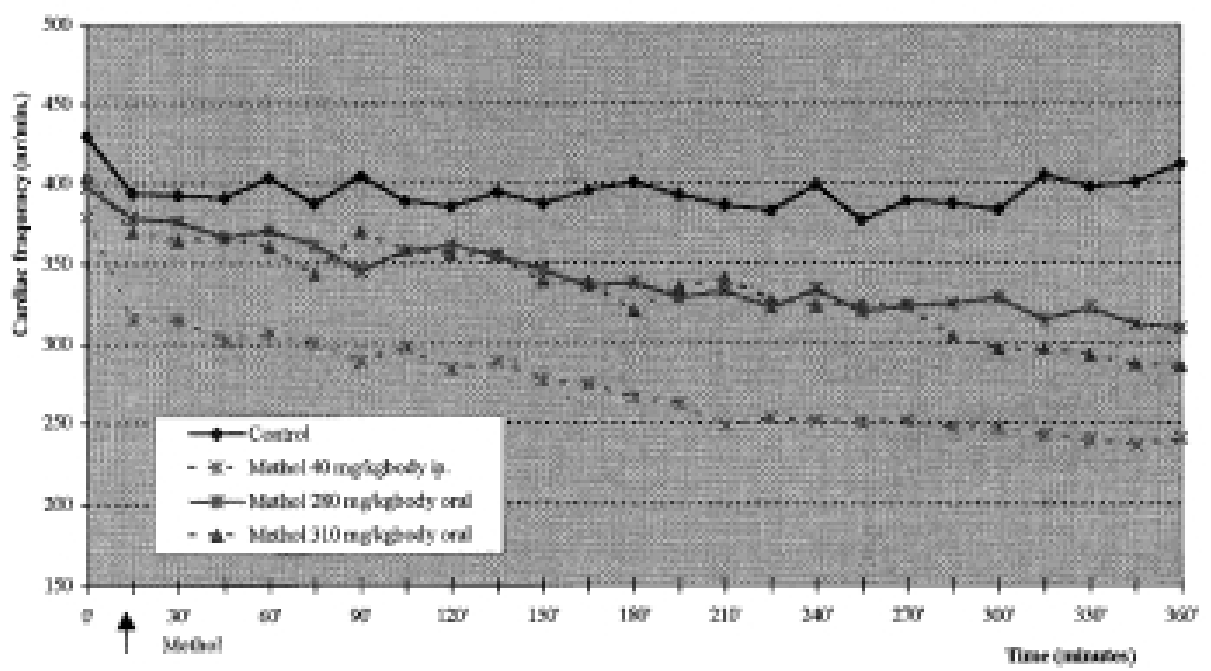

Fig. 1. The variations of cardiac frequency due to methol in rats

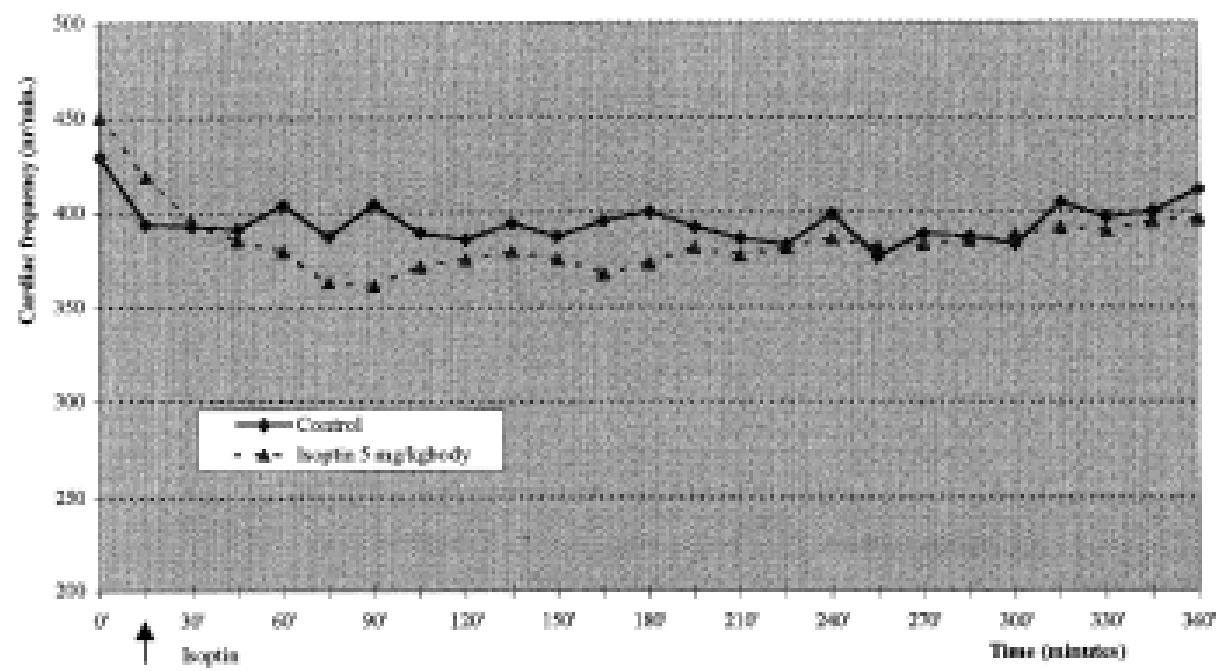

Fig. 2. The variations of cardiac frequency due to isoptin 


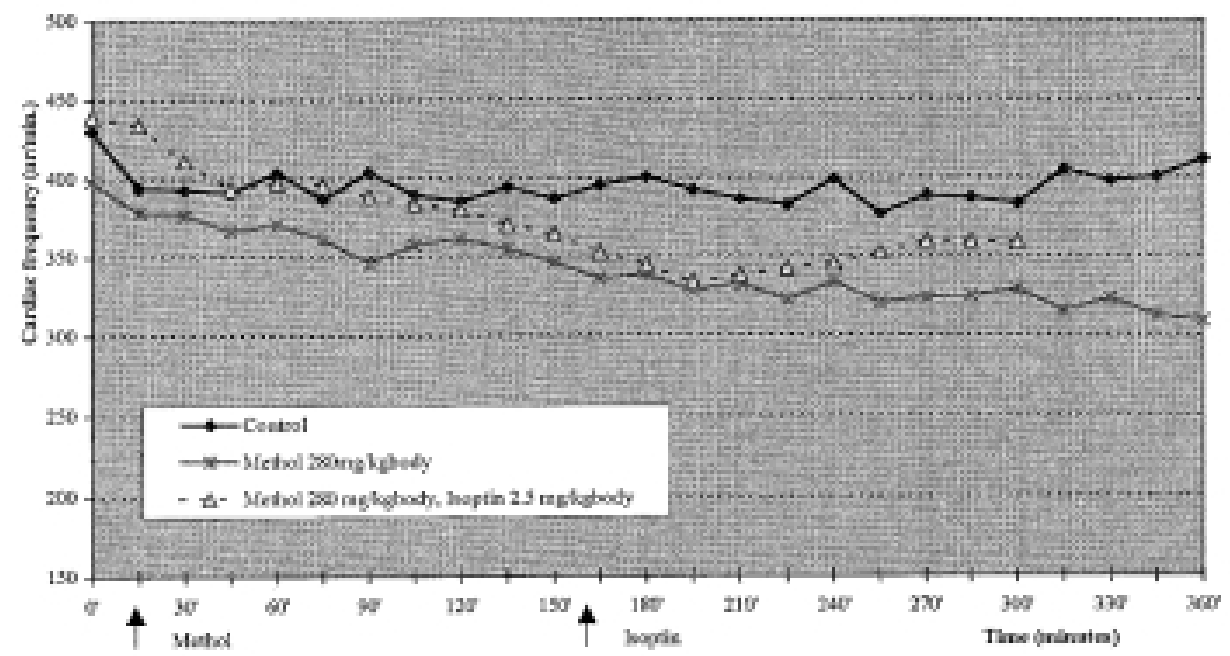

Fig. 3. The variations of cardiac frequency due to methol in presence of isoptin

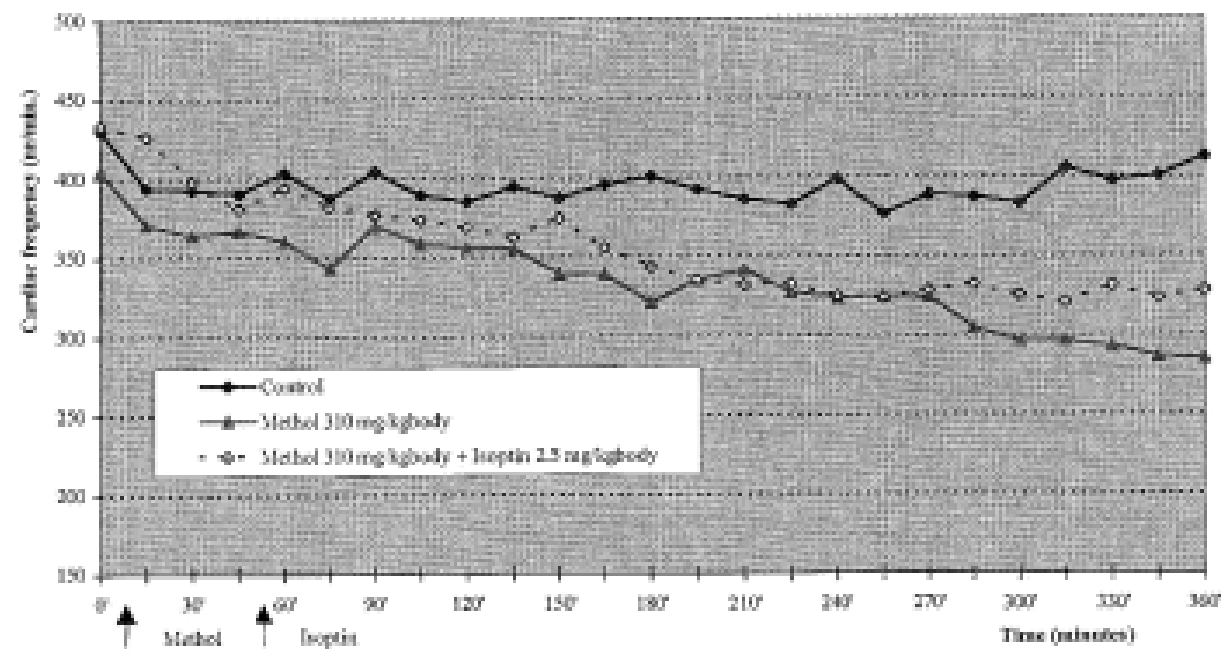

Fig. 4. The variations of cardiac frequency due to methol in presence of isoptin 


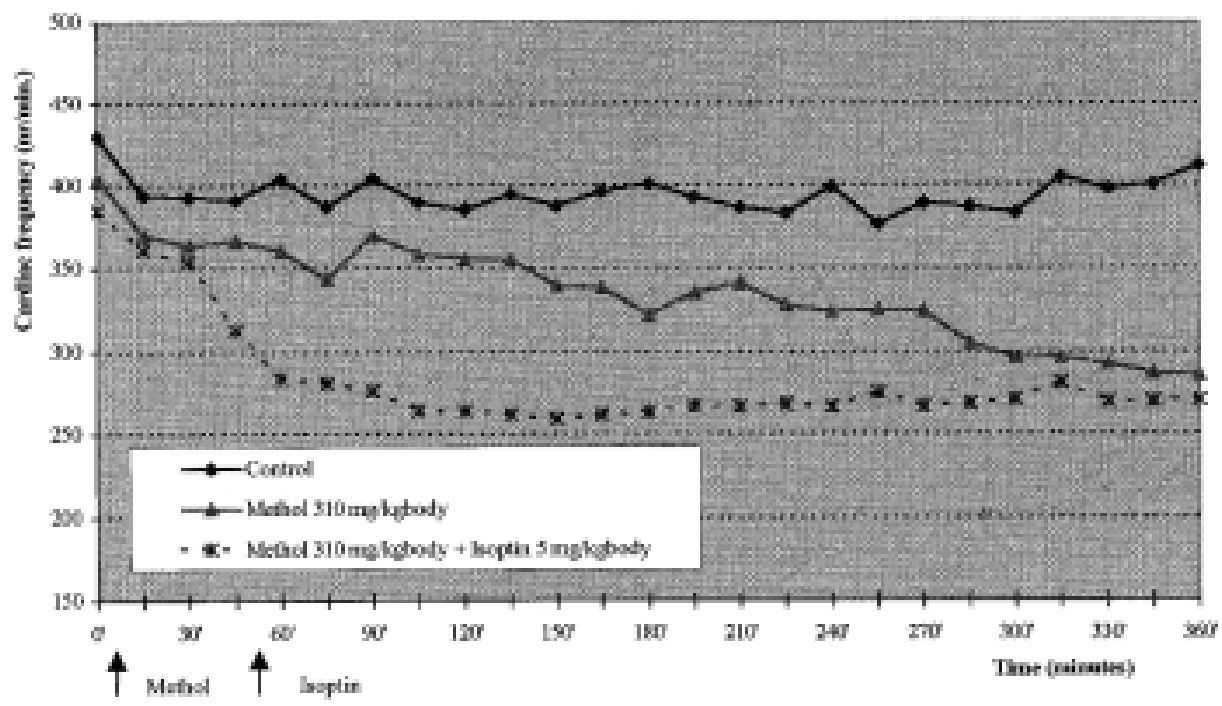

Fig. 5. The variations of cardiac frequency due to methol in presence of isoptin

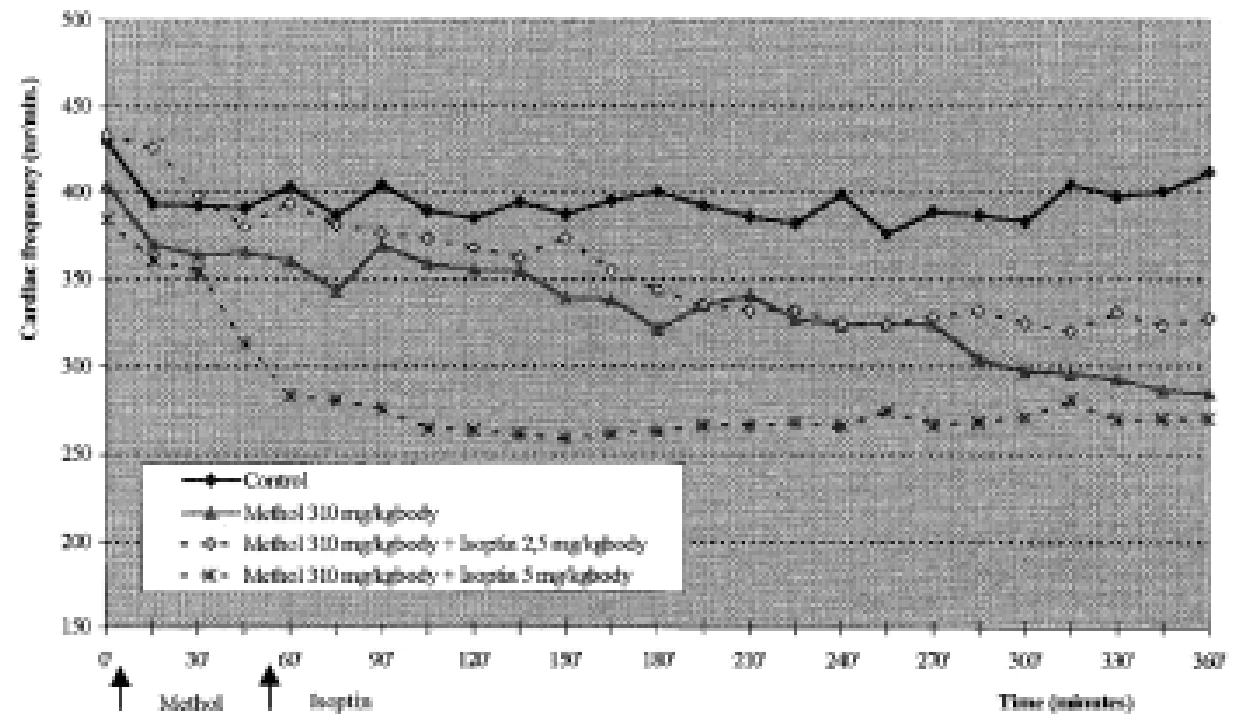

Fig. 6. The variations of cardiac frequency due to methol in presence of isoptin 
Control

I. $\quad \mathrm{t}=0$,

Methol 310 mg/kgbody oral

II. $\mathrm{t}=30^{\prime}$

III. $\mathrm{t}=2 \mathrm{~h} 30^{\prime}$

IV. $\mathrm{t}=5 \mathrm{~h}$

V. $t=16 \mathrm{~h}$

VI. $\quad \mathrm{t}=21 \mathrm{~h}$

Control

I. $\mathrm{t}=0$,

Isoptin $10 \mathrm{mg} / \mathrm{kgbody}$ ip.

II. $\mathrm{t}=45$,

III. $\mathrm{t}=1 \mathrm{~h} 30^{\prime}$

IV. $\mathrm{t}=2 \mathrm{~h}$

Isoptin $10 \mathrm{mg} / \mathrm{kgbody}$ ip.

V. $\quad \mathrm{t}=6 \mathrm{~h}$

VI. $\mathrm{t}=7 \mathrm{~h} 30^{\prime}$

Isoptin $10 \mathrm{mg} / \mathrm{kgbody}$ ip.

VII. $\mathrm{t}=8 \mathrm{~h}$

VIII. $\quad \mathrm{t}=8 \mathrm{~h} 30^{\circ}$

IX. $\mathrm{t}=9 \mathrm{~h}$

Acta Physiologica Hungarica 87, 2000

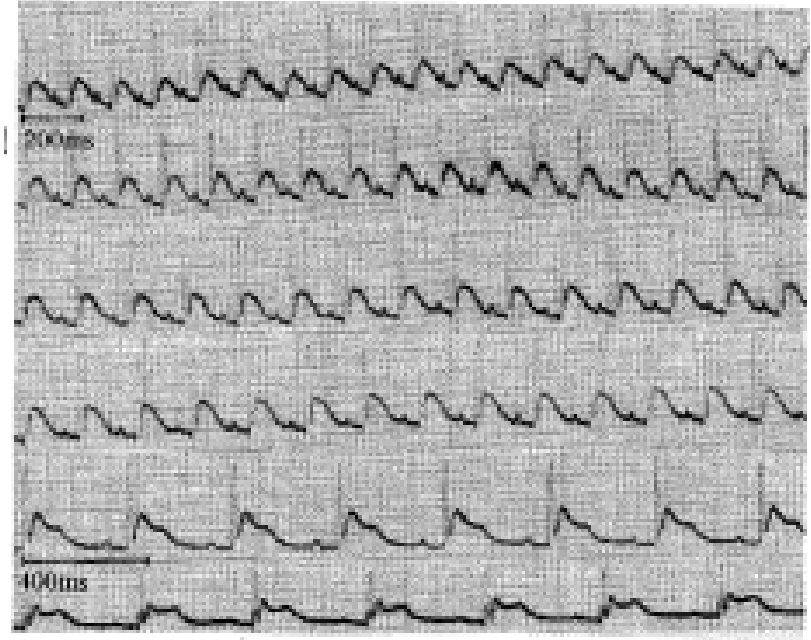

Fig. 7a. ECG route due to methol in rats

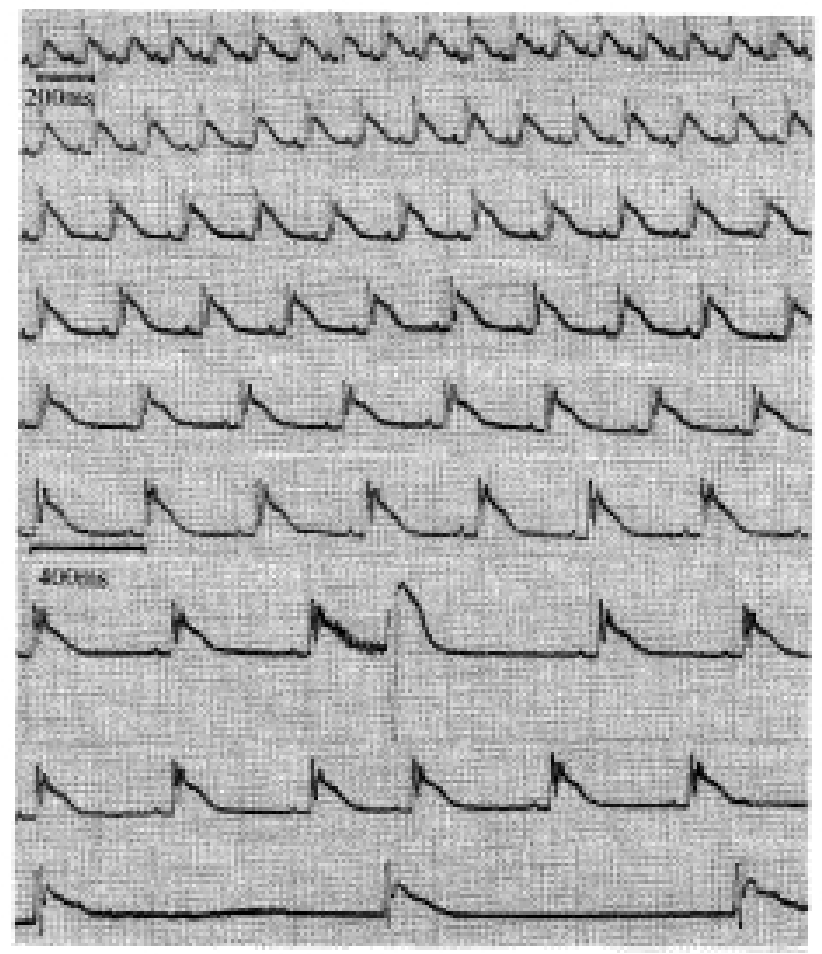

Fig. 7b. ECG route due of isoptin in rats 
ECG curve in rats (Fig. 5) with oral administration of $310 \mathrm{mg} / \mathrm{kg} / \mathrm{bw}$. methol: after methol administration sinusal bradycardia develops which later on is exacerbated, see curves II-IV. Bradycardia increases in time by the extension of $\mathrm{P}-\mathrm{R}$ interval and $\mathrm{T}$ wave as well (disorders of atrial conduction and of repolarization) see curves V-VI.

The ECG curve of rats with intraperitoneal administration of isoptin: after $10 \mathrm{mg} / \mathrm{kg} / \mathrm{bw}$. isoptin administration sinusal bradycardia develops, see curves I-IV. This bradycardia becomes more marked following the second dose of $10 \mathrm{mg} / \mathrm{kg} / \mathrm{bw}$. isoptin, see curves V-VI and after the third dose of $20 \mathrm{mg} / \mathrm{kg} / \mathrm{bw}$. isoptin more severe bradycardia is assessed with the occurrence of extrasystoles, see curve VII., of arrhytmia, see curve VIII., and of ventricular rhytm (lack of P wave), see curve IX.

Table I includes the mean values of the heart rate of the animal groups, standard deviations, as well as the values of significant differences the heart rate of the lots as compared with the controls.

\section{Discussions}

The effect of methol on the preparation of RV papillary muscle and striated muscle is revealed by the increase of muscle tone and by the decrease of the amplitude of muscular contraction [4]. In acute methol $\left(\mathrm{DL}_{100}\right)$ intoxications in rats the death of animals is produced 2-5 days after the date of methol intoxication. The ECG curve shows that the death of animals is due to the cardiac activity disorders consisting in sinusal bradycardia exacerbated in time by gradually slowing down the conduction speed in the ventricular musculature, in the formation of supranodal and supraventricular ectopic pace-maker, in shortening the P-R interval with ventricular and supraventricular extrasystoles, in the isomeric atrioventricular dissociation and in the electromagnetic dissociation followed by cardiac stop [3].

Methol inhibits $\mathrm{Ca}^{2+} \mathrm{ATP}$-ase activity [6], the inhibitors of the SR $\mathrm{Ca}^{2+}$ pump in the smooth muscle tissue block the refilling of the intercellular $\mathrm{Ca}^{2+}$ deposits $[1,17]$, and they produce a sustained contraction of the vascular smooth muscle [20], at the same time they affect the functions of the striated and smooth muscle cells, namely: contraction, ion concentration and membrane excitability [22]. By blocking $\mathrm{Ca}^{2+} \mathrm{ATP}-$ ase by methol, $\mathrm{Ca}^{2+}$ accumulates in the cytoplasm of the muscle fibre, producing the increase of the muscle tone. Probably methol has an effect on the cells of the sinoatrial node, too, which is the place of formation of the electric impulses that determine cardiac activity, and thereby it leads to the decrease of the heart rate. The decrease of the heart rate depends on the methol dose, as well as on the period of time from the administration [5]. Isoptin administration produces a more marked decrease of the heart rate followed by its increase. Isoptin is a calcium-channel blocker with special effect at 
the level of the sinusal and atrioventricular nodes [2]. By blocking the calcium channels $[14,21]$ the entrance of calcium into the cytoplasm is prevented, and thus the concentration of cytoplasmic calcium decreases; this phase in our case is exteriorized by stopping the decrease of the heart rate. Isoptin in a dose of $2.5 \mathrm{mg} / \mathrm{kg} / \mathrm{bw}$. has a better effect as compared with the dose of $5 \mathrm{mg} / \mathrm{kg} / \mathrm{bw}$. in acute methol intoxication, because it does not produce a sudden decrease of the heart rate. The dose of $5 \mathrm{mg} / \mathrm{kg} / \mathrm{bw}$. isoptin blocks the majority of calcium channels, producing a sudden change in the concentration of intracellular calcium. The use of isoptin as an "antidote" with a view to counteract the effect of methol on the cardiac activity in acute intoxications of experimental animals necessitates further studies.

\section{REFERENCES}

1. Darby, P. J., Kwan, C. Y., Daniel, E. E.: Use of calcium pump inhibitors in the study of calcium regulation in smooth muscle. Biol. Sign. 2(5), 293-304 (1993).

2. Dobrescu, D.: Practical pharmacotherapy. (in Romanian), Vol II. 1989, Ed. Med. p. 232.

3. Domahidi, I., Egyed-Zsigmond, I., Kolozsvári, É., Peti, A.: The acute effect and histopathological changes produced by methol in experimental animals. (in Romanian), Revista Româna de Medicina Muncii 48 (3-4), 10015-10019 (1998).

4. Domahidi, I.: The effect of methol, hydroquinone and black-white Azomures developer solution on muscular activity. (in Romanian), Revista Românǎ de Medicina Muncii 47 (1-2), 877-884 (1997).

5. Domahidi, I., Farkas, J., Hála, O., Drăgoi, S., Chele, M., Pelok, B. Gy., Peti, A.: The in vivo and in vitro effect of methol on cardiac and respiratory activity in experimental animals. (in Romanian), The XXIV-th Annual Scientific Session of Public Health Center, Abstract Volume p. 33 (1998).

6. Domahidi, I., Hála, O., Jakab, Gy.: The action of methol on $\mathrm{Ca}^{2+}$ ATP-ase enzyme activity of rabbit sarcoplasmic reticulum. (in Romanian), Revista Românǎ de Medicina Muncii 47 (1-2), 877-884 (1997).

7. Dux, L., Martonosi, A. N.: The regulation of ATP-ase - ATP-ase interactions in sarcoplasmic reticulum membrane I. The effects of $\mathrm{Ca}^{2+} \mathrm{ATP}$ and inorganic phosphate. J. Biol. Chem. 258, 11896-11902 (1983).

8. Dux, L., Martonosi, A. N.: The regulation of ATP-ase - ATP-ase interactions in sarcoplasmic reticulum membrane II. The influence of membrane potential. J. Biol. Chem. 258, 11903-11907 (1983).

9. Ebashi, S.: Regulation of muscle contraction the Croonian lecture. Proc. R. Soc. 207, 259-286 (1980).

10. Fiskum, G., Lehninger, A. L.: The mechanism and regulation of mitochondrial $\mathrm{Ca}^{2+}$ transport. Fed. Proc. Fed. Am. Soc. Exp. Biol. 39, 2432-2436 (1980).

11. Hasselbach, W.: The sarcoplasmic calcium pump. A model of energy transduction in biological membrane. Topics in Current Chem. 78, 1-56 (1979).

12. Jacobs, J. M., Meyer, T.: Control of action potential-induced $\mathrm{Ca}^{2+}$ signaling in the soma of hippocampal neurons by $\mathrm{Ca}^{2+}$ release from intracellular stores. J. Neurosci. 17(11), 4129-4135 (1997).

13. Jarish, R., Sándor, I.: Standard epicutaneous testing: 5-year results and their effects on future examinations. Z. Hautkr. 53(13), 462-470 (1978).

14. Khanzode, S. D., Mahakalkar, S. M., Belorkar, N. R.: Effect of pre-treatment of some calcium channel blockers on catalepsy and stereotypic behaviour in rats. Indian J. Physiol. Pharmacol. 40(2), 159-162 (1996). 
15. Martonosi, A. M.: Transport of calcium by sarcoplasmic reticulum in calcium and cell functions. III. ed. WY Cheung Academic Press, 1982, p 37-102.

16. Meissner, G.: Ryanodine receptor/ $\mathrm{Ca}^{2+}$ release channels and their regulation by endogenous effectors. Annu. Rev. Physiol. 56, 485-508 (1994).

17. Rohács, T., Bagó, A., Deák, F.: Capacitative $\mathrm{Ca}^{2+}$ influx in adrenal glomerulosa cells: possible role in angiotensin II. response. Am. J. Physiol. 267 (5 pt 1), 1246-1252 (1994).

18. Schneider, M. F., Chandler, W. K.: Voltage dependent charge movement in skeletal muscle: a possible step in excitation-contraction coupling. Nature 242, 244-246 (1973).

19. Schnetkamp, P. P.: Functional expression of Na-Ca exchanger clonas measured with the fluorescent $\mathrm{Ca}^{2+}$-indicating dye fluo-3. Biochem. Cell. Biol. 74(4), 535-539 (1996).

20. Shimamoto, H., Majarais, I. L., Shimamoto, Y.: Role of sarcoplasmic reticulum in the contractile function of vascular smooth muscle as studied by 2,5-di-(tert-butyl)-1,4-benzohydroquinone. Biol. Sign. 1(4), 182-193 (1992).

21. Trequattrini, C., Petris, A., Franciolini, F.: Characterisation of a neuronal delayed rectifier K current permanent to Cs and blocked by verapamil. J. Membr. Biol. 154(2), 143-153 (1996).

22. Watanabe, M., Shigekawa, M.: Physiological functions of endoplasmic and sarcoplasmic reticulum calcium pump and pharmacology of inhibitors of the pump. Nippon Yakurigaku Zasshi 102, 171-180 (1993). 